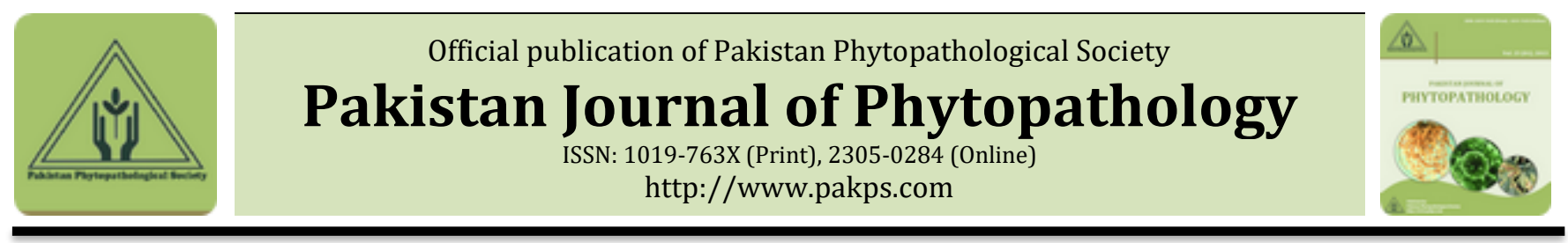

\title{
OCCURRENCE OF A2 MATING TYPE AND MICROMORPHOLOGY OF OOSPORES OF PHYTOPHTHORA INFESTANS IN GOLESTAN PROVINCE OF IRAN
}

\author{
Zolfaghary Amir
}

Department of Plant Protection, Gorgan Branch, Islamic Azad University, Gorgan, Iran.

\begin{abstract}
A B S T R A C T
The aim of this study was to determine the mating types, origin and micromorphology of oospores of Ph. infestans isolated from the potato fields in Golestan province of Iran during 2014-16. In total, 197 isolates were assessed for mating type. The average frequencies of mating types $A_{1}$ and $A_{2}$ were 85.8 and $14.2 \%$ respectively. $A_{2}$ mating type was found only from two regions. A total of 9 self-fertile isolates $(5.3 \%)$, which only belonged to the $\mathrm{A}_{1}$ mating type were detected. The average value for oospore production index (OPI) within the interaction zone between the two isolates was estimated one (very low) in $A_{1} \times A_{1}$ and four (very high) in $A_{1} \times A_{2}$ crosses. Oospores of hybrid origin were observed in $A_{1} \times A_{2}$ and self-fertile oospores only in $A_{1} \times A_{1}$ paired cultures. Parthenogenetic oospores (without antheridia) were not observed in $A_{1} \times A_{1}$ or $A_{2} \times A_{2}$ paired cultures. The results of oospores micromorphology indicated that the antheridia in hybrid oospores were amphigynous and from half spheric to nearly spheric, almost hyaline, from 18.5$23.5 \times 10.5-15.5 \mu \mathrm{m}$ in size. Oogonia were nearly spheric from nacarat to brown in colour. The colour of the hybrid oospores varied from brown to dark-brown, spheric, varied from 25-35 $\mu \mathrm{m}$ in diameter with two thick walls with thickness of 2.5-5.5 $\mu \mathrm{m}$. The self-fertile oospores were with a thin wall with thickness of $1.5 \mu \mathrm{m}$, spherical and varied from 40-60 $\mu \mathrm{m}$ in diameter. The monitoring of $A_{1}$ and $A_{2}$ mating type ratios of oospores are important to aid in the prediction of the extent of sexual recombination and thus the risk of long-lived oospores serving as primary inoculum sources in the main potato production regions.
\end{abstract}

Keywords: Iran, Mating type, Micromorphology, Oospore, Oomycetes, Potato, Phytophthora infestans.

\section{INTRODUCTION}

Potato late blight, a disease caused by Phytophthora infestans (Mont.) de Bary is one of the most devastating plant diseases worldwide (Shaw, 1996) including Iran, especially in Golestan province. The disease was first reported from north of Iran in 1965 (Ershad, 2009). Golestan is one of the 31 provinces of Iran, located in the north-east of the country, south of the Caspian Sea

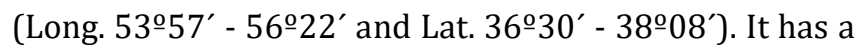
moderate and humid climate known as "the moderate Caspian climate". About 10 to 15 percent of the country's potato crop is produced in irrigated farms of this province (Aghajani, 2015).

\section{Submitted: March 27, 2018}

Revised: May 045, 2018

Accepted for Publication: May 25, 2018

* Corresponding Author:

Email: amir.zolfaghary@gmail.com

(C) 2017 Pak. J. Phytopathol. All rights reserved.
According to the Ministry of Agriculture Bureau in Golestan province, the potato late blight reached an epidemic level in 2006 in Golestan and resulted in severe damage to the crop (Sadravi, 2008). The same disease also reached an epidemic in Ardabil province of Iran (located in north-west of the country not very far from the Caspian Sea) in 1997 and caused an 80\% crop loss (Zargarzadeh et al., 2008)

$P h$ infestans is a heterothallic oomycete with two mating types, $A_{1}$ and $A_{2}$ (Lehtinen et al., 2009). Interaction between hyphae of opposite mating type can result in the formation of oospores. Initially, both $A_{1}$ and $A_{2}$ mating types were found only in central Mexico (Gallegly, 1958; Smoot et al., 1958); while $A_{1}$ alone distributed worldwide (Drenth et al., 1995). Later on $A_{2}$ which was earlier restricted to the Central Mexico only also reported from Switzerland (Hohl and Islen, 1984) and in many other countries in Europe, Africa, Asia and the America (Spielman et al., 1991; Fry et al., 1993; Drenth et al., 1995). 
Appearance of $\mathrm{A}_{2}$ mating type led to reproducing sexually of heterothallic Ph. infestans, then producing oospores and recombining sexually by oospores formation. Oospores are able to overwinter in the remainders and soil, thereby it become new sources of infection and increase possibilities of more serious epiphytotics. Sexual reproduction results in a wider variety of genotypes (Zhang et al., 2001) and more diverse in Ph. infestans populations (Drenth et al., 1995) which might contain more virulent isolates or races which enabled the pathogen to avoid recognition by any specific resistance gene, or combinations of resistance genes in the potato population. Since fungicide resistance isolates produced through sexual recombination, some fungicides will lose the value of application (Zhang et al., 2001).

The aim of this study was to determine the mating types, origin and micromorphology of oospores of Ph. infestans in isolates obtained from the potato growing regions from different fields in Golestan province of Iran, during 2014-16.

\section{MATERIALS AND METHODS}

Collection of samples: During 2014-16, samples of blighted potato leaves were collected from most of the potato growing regions from different fields in Golestan province of Iran (Table 1). Samples were placed in labeled paper envelopes and transferred to the laboratory for isolation of the pathogen.

Table 1. Frequency of mating types for Phytophthora infestans isolates from blighted potato leaves from five regions from different potato fields in Golestan province of Iran.

\begin{tabular}{|c|c|c|c|c|c|c|}
\hline \multirow[t]{2}{*}{ Year } & \multirow[t]{2}{*}{ Region } & \multirow[t]{2}{*}{ Cultivar } & \multirow[t]{2}{*}{ Isolates } & \multicolumn{2}{|c|}{ Mating types } & \multirow[t]{2}{*}{$\begin{array}{c}\text { A } 1 \text { Self-fertile }^{\text {is }} \\
\text { isolates }\end{array}$} \\
\hline & & & & $\mathrm{A}_{1}$ & $\mathrm{~A}_{2}$ & \\
\hline \multirow{5}{*}{2014} & Valikabad & Agria & 20 & $15(75)^{\mathrm{a}}$ & $5(25)$ & 2 \\
\hline & Feyzabad & Marfona & 18 & $14(77.8)$ & $4(22.2)$ & 1 \\
\hline & Jelin & Sante & 12 & $12(100)$ & $0(0)$ & 0 \\
\hline & Sorkhankalateh & Arinda & 10 & $10(100)$ & $0(0)$ & 0 \\
\hline & Marzankalateh & Draga & 10 & $10(100)$ & $0(0)$ & 0 \\
\hline Total & & & 70 & $61(87.1)$ & 9 (12.9) & $3(4.9)$ \\
\hline \multirow{5}{*}{2015} & Valikabad & Agria & 18 & $12(66.7)$ & $6(33.3)$ & 2 \\
\hline & Feyzabad & Marfona & 14 & $9(64.3)$ & $5(35.7)$ & 1 \\
\hline & Jelin & Sante & 14 & $14(100)$ & $0(0)$ & 0 \\
\hline & Sorkhankalateh & Arinda & 12 & $12(100)$ & $0(0)$ & 0 \\
\hline & Marzankalateh & Draga & 12 & $12(100)$ & $0(0)$ & 0 \\
\hline Total & & & 70 & 59 (84.3) & 11 (15.7) & $3(5.1)$ \\
\hline \multirow{5}{*}{2016} & Valikabad & Agria & 16 & $12(75)$ & $4(25)$ & 2 \\
\hline & Feyzabad & Marfona & 15 & $11(73.3)$ & $4(26.7)$ & 1 \\
\hline & Jelin & Sante & 10 & $10(100)$ & $0(0)$ & 0 \\
\hline & Sorkhankalateh & Arinda & 9 & $9(100)$ & $0(0)$ & 0 \\
\hline & Marzankalateh & Draga & 7 & $7(100)$ & $0(0)$ & 0 \\
\hline \multirow[t]{2}{*}{ Total } & & & 57 & $49(86)$ & $8(14)$ & $3(6.1)$ \\
\hline & al number & & 197 & $169(85.8)$ & $28(14.2)$ & $9(4.6)$ \\
\hline
\end{tabular}

a: Percentage of mating type isolates.

Isolation and maintenance of Ph. Infestans: Isolation was made by placing blighted leaf fragments on potato tuber slices (about $5 \mathrm{~mm}$ thickness) of a susceptible cultivar (Agria) in sterilized humid chambers and incubating at $18^{\circ} \mathrm{C}$. After $5-7$ days, pathogen grew on the surface of the tuber slices. After visible intensive sporulation, mycelium with zoosporangia was transferred onto a small piece of a surface-sterilized tuber of cv. Agria. These pieces were put on rye B agar culture media (Caten and Jinks, 1968) with antibiotic mixture (Ampicillin, Rifamycin, Vancomycin) and fungicide (Benomyl at a concentration of $500 \mathrm{ppm}$ ). Cultures were incubated in the dark at $18^{\circ} \mathrm{C}$ and transferred every 3-4 weeks. Stock cultures of all isolates were maintained on slants of rye A agar culture media at $15^{\circ} \mathrm{C}$ for further studies. In total, 197 pure isolates of $P h$. infestans were obtained from the different potato fields in Golestan province of Iran.

Determination of mating types: The mating type of an isolate was determined by pairing of unknown isolates 
with standard tester strains $\mathrm{A}_{1}$ and $\mathrm{A}_{2}$ (Ph. infestans) on rye $B$ agar (Forbes, 1997) with tomato juice (Rafiee and Banihashaemi, 2015). A 5-mm agar discs of Ph. infestans were cut from the edge of 7-day-old culture of unknown mating type and paired $4 \mathrm{~cm}$ apart from a similar agar disc of either the $A_{1}$ or $A_{2}$ standard tester strain (dual culture) on the center of a rye B agar Petri dish $(9 \mathrm{~cm})$. Inoculated Petri dishes were incubated at $15-$ $18^{\circ} \mathrm{C}$ in the dark for about 14 days or until oospores were formed (Tooley et al., 1989). Four plates were prepared for each paired culture. After two weeks, each paired culture was mixed with $100 \mathrm{ml}$ distilled water in a blender at high speed for $1 \mathrm{~min}$. The oospore formation was examined by placing a single 10- $\mu \mathrm{l}$ droplet by a micropipette on the microscopic slide for the presence or absence of oospores (Mazakova et al., 2006).

Also, from the interface of two growing cultures mycelial plugs were randomly removed with the help of corkborer, squashed over microscopic slide and observed under the light microscope (Nikon: ALPHAPHOT-2 YS2). When oospores with antheridia formed in the $\mathrm{A}_{2}$ pairing and did not form in the unknown isolate colony, the unknown isolate was rated as an $A_{1}$. If oospores with antheridia formed in the $A_{1}$ pairing and not the unknown isolate colony, the unknown isolate was rated as an $\mathrm{A}_{2}$ (Smirnov and Elansky, 1999).

Determination of self-fertile isolates: When oospores with antheridia formed in the $A_{1} \times A_{1}$ or $A_{2} \times A_{2}$ paired cultures, it was rated as a self-fertile isolate (Smirnov, 2001).

Determination of parthenogenetic isolates: When oospores without antheridia formed in the $A_{1} \times A_{1}$ or $A_{2} \times A_{2}$ paired cultures, it was rated as a parthenogenetic isolate (Smirnov, 2001).

Determination of origin of oospores: Each unknown isolate of $P h$. infestans after determination of mating type $\left(A_{1}\right.$ or $\left.A_{2}\right)$ was paired and self-paired on Petri dishes containing rye $\mathrm{B}$ agar with tomato juice. After this, inoculated Petri dishes were incubated at $15-18^{\circ} \mathrm{C}$ in the dark for about 21 days. Oospores based on their origin were categorized to three groups: hybrid, selffertile and parthenogenetic. If $\mathrm{A}_{1} \times \mathrm{A}_{2}$ paired cultures produced oospores with antheridia, it was rated as a hybrid oospore (Zhang et al., 2001). If $A_{1} \times A_{1}$ or $A_{2} \times A_{2}$ paired cultures produced oospores with antheridia, it was rated as a self-fertile oospore (Zhang et al., 2001; Smirnov and Elansky, 1999). If $A_{1} \times A_{1}$ or $A_{2} \times A_{2}$ paired cultures produced oospores without antheridia, it was rated as a parthenogenetic oospore (Zhang et al., 2001).

Determination of oospore production index (OPI): Oospore production index was estimated based on examination of 10 microscopic fields $\left(0.2 \mathrm{~mm}^{2}\right.$ each) within the interaction zone of the two parental cultures (Smoot et al., 1958). The zone in which oospores were formed was first located, and 10 microscopic fields were selected by random movement of the mechanical stage along this zone. The number of oospores in a crosssection from the agar surface to the bottom of the plate was quantified using an oospore production index (OPI). The OPI represents average oospore production in the mating region and is expressed in four classes: 0,0 oospores $\mathrm{mm}^{-2}$ (zero); 1, 1-50 oospores $\mathrm{mm}^{-2}$ (very low); 2, 51-250 oospores $\mathrm{mm}^{-2}$ (medium); 3, 251-500 oospores $\mathrm{mm}^{-2}$ (high) and $4,>500$ oospores $\mathrm{mm}^{-2}$ (very high) (Flier et al., 2001).

Micromorphology of oospores: The micromorphology of oospores was examined based on the presence of antheridia, presence and shape of oogonia, oospore diameter and wall thickness with a bright-field microscope at $\times 40$ (Cohen et al., 1997).

\section{STATISTICAL ANALYSIS}

All statistical analysis were performed using the SPSS v. 22 and Minitab v. 18 statistical packages.

\section{RESULTS}

Mating types: A total of 197 isolates of Ph. infestans isolated from blighted potato leaves collected from the most of the potato growing regions from different fields in Golestan province of Iran. Among them 169 isolates (85.8\%) belongs to the $A_{1}$ mating type, 28 isolates belongs to the $\mathrm{A}_{2}$ mating (14.2\%) isolated from only two regions: Valikabad and Feyzabad. In 2014, the ratio of $A_{1}$ to $A_{2}$ mating types was $87: 13$, in 2015 , the ratio was $84: 16$ and in 2016, the ratio was $86: 14$ for the benefit of $A_{1}$ mating type (almost 6:1) for every three years. The hierarchical cluster analysis of percentage of frequency of 197 isolates of Ph. infestans using Ward's method and squared Euclidean distance indicated that isolates grouped into two distinct clusters. Cluster I consisted of isolates from Valikabad and Feyzabad and had $A_{1}$ and $A_{2}$ mating types. Cluster II consisted of isolates from Jelin, Sorkhankalateh and Marzankalateh with the $A_{1}$ mating type (Figure 1). 


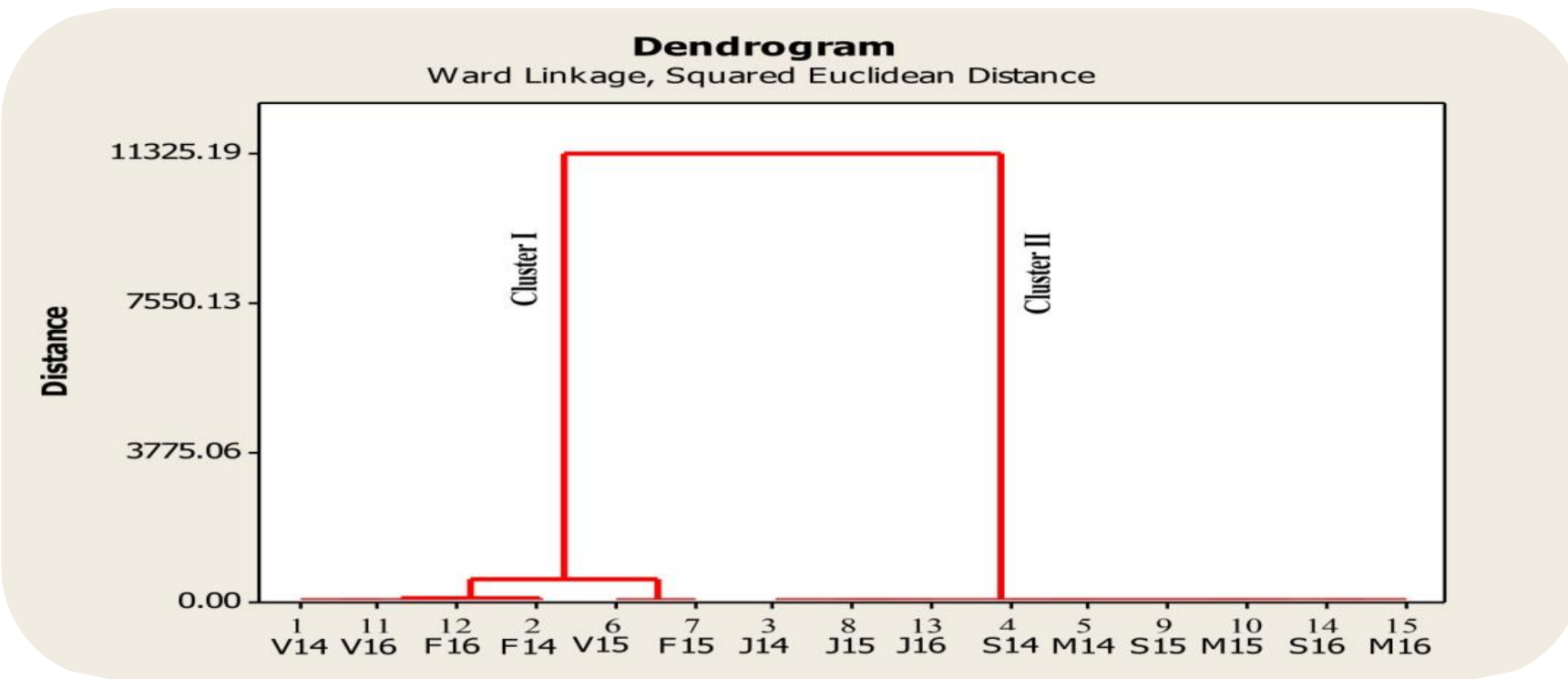

Figure 1. Clustering tree of percentage of frequency of 197 isolates of Phytophthora infestans during 2014-16 from the five potato growing regions in Golestan province of Iran using Ward's method and squared Euclidean distance.

Isolates:

* V14: Valikabad 2014, V15: Valikabad 2015, V16: Valikabad 2016.

* F14: Fazelabad 2014, F15: Fazelabad 2015, F16: Fazelabad 2016.

* J14: Jelin 2014, J15: Jelin 2015, J16: jelin 2016.

* S14: Sorkhankalateh 2014, S15: Sorkhankalateh 2015, S16: Sorkhankalateh 2016.

* M14: Marzankalateh 2014, M15: Marzankalateh 2015, M16: Marzankalateh 2016.

Self-fertile isolates: During 2014-16, out of 169 isolates of Ph. infestans of $\mathrm{A}_{1}$ mating type, 9 were found self-fertile isolates (5.3\%), including six isolates from Valikabad and three isolates from Feyzabad.

Parthenogenetic isolates: None of the 197 isolates were
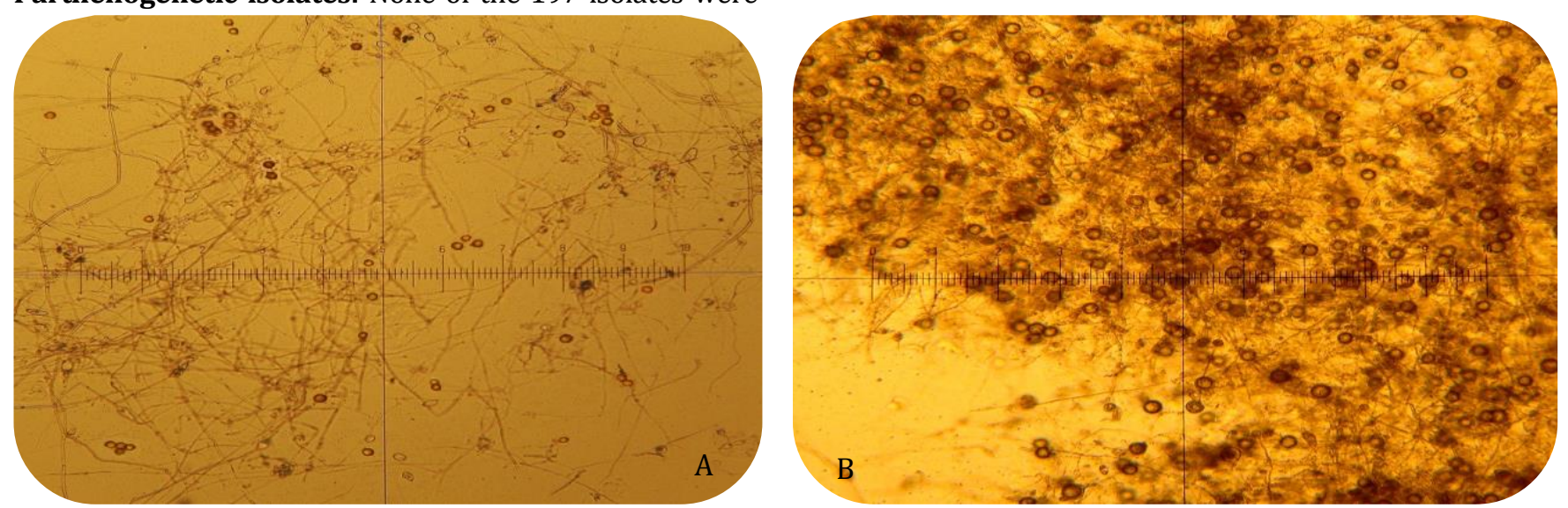

Figure 2. Oospores of Phytophthora infestans in microscopic field $\left(0.2 \mathrm{~mm}^{2}\right)$, A) 1, 1-50 oospores (very low) in $\mathrm{A}_{1}$ self-fertile isolates, $\mathrm{B}) 4,>500$ oospores (very high) in $\mathrm{A}_{1} \times \mathrm{A}_{2}$ crosses. $\left(0,0\right.$ oospores $\mathrm{mm}^{-2}$ (zero); $1,1-50$ oospores $\mathrm{mm}^{-2}$ (very low); 2,51 -

found parthenogenetic.

Origin of oospores: In $A_{1} \times A_{2}$ paired cultures, oospores with antheridia (hybrid) were produced in great abundance. Self-fertile oospores (with antheridia) were observed only in $A_{1} \times A_{1}$ paired cultures. No oospores were produced in $\mathrm{A}_{2} \times \mathrm{A}_{2}$ paired cultures. Parthenogenetic oospores (without antheridia) were not observed in $\mathrm{A}_{1} \times \mathrm{A}_{1}$ or $\mathrm{A}_{2} \times \mathrm{A}_{2}$ paired cultures.

Oospore production index (OPI): The average value for oospore production index (OPI) at the interaction zone between the two isolates was estimated one (very low) in $\mathrm{A}_{1}$ self-fertile isolates from Valikabad and Feyzabad and four (very high) in $\mathrm{A}_{1} \times \mathrm{A}_{2}$ crosses from all five regions (Figure 2).

(1)

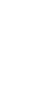


250 oospores $\mathrm{mm}^{-2}$ (medium); 3, 251-500 oospores $\mathrm{mm}^{-2}$ (high) and 4, $>500$ oospores $\mathrm{mm}^{-2}$ (very high) (Flier et al., 2001).

Micromorphology of oospores: The antheridia in hybrid oospores from $\mathrm{A}_{1} \times \mathrm{A}_{2}$ paired cultures were amphigynous and from half spheric to nearly spheric, almost hyaline, from 18.5-23.5 × 10.5-15.5 $\mu \mathrm{m}$ in size. Oogonia were nearly spheric from nacarat to brown in colour. The colour of the hybrid oospores varied from

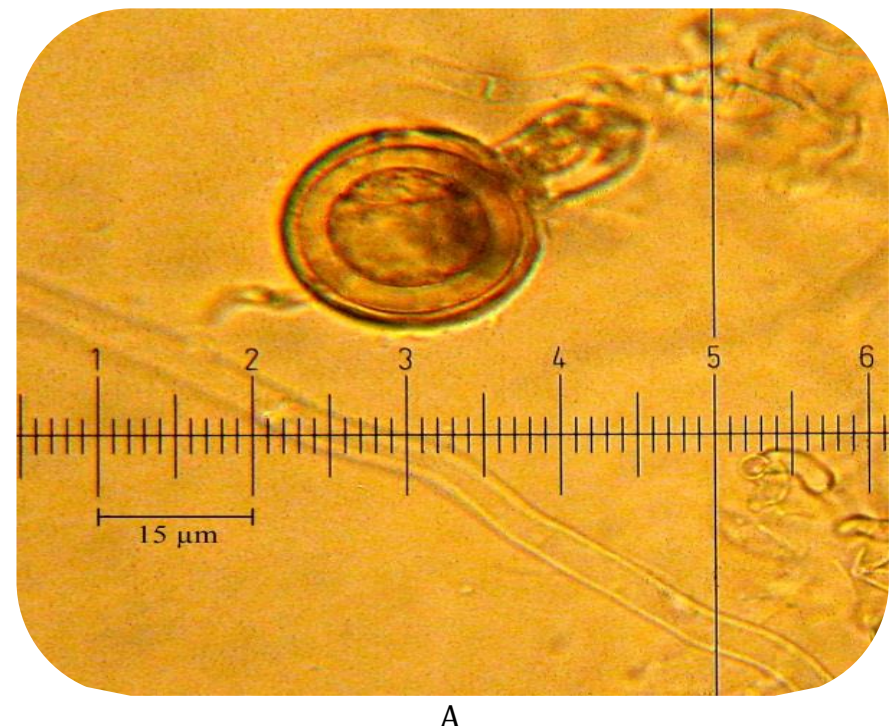

brown to dark-brown, spheric, varied from 25-35 $\mu \mathrm{m}$ in diameter with two thick walls with thickness of 2.5 $5.5 \mu \mathrm{m}$. The self-fertile oospores from $A_{1} \times A_{1}$ paired cultures were with a thin wall with thickness of 1.5 $\mu \mathrm{m}$, spherical and varied from 40-60 $\mu \mathrm{m}$ in diameter (Figure 3).

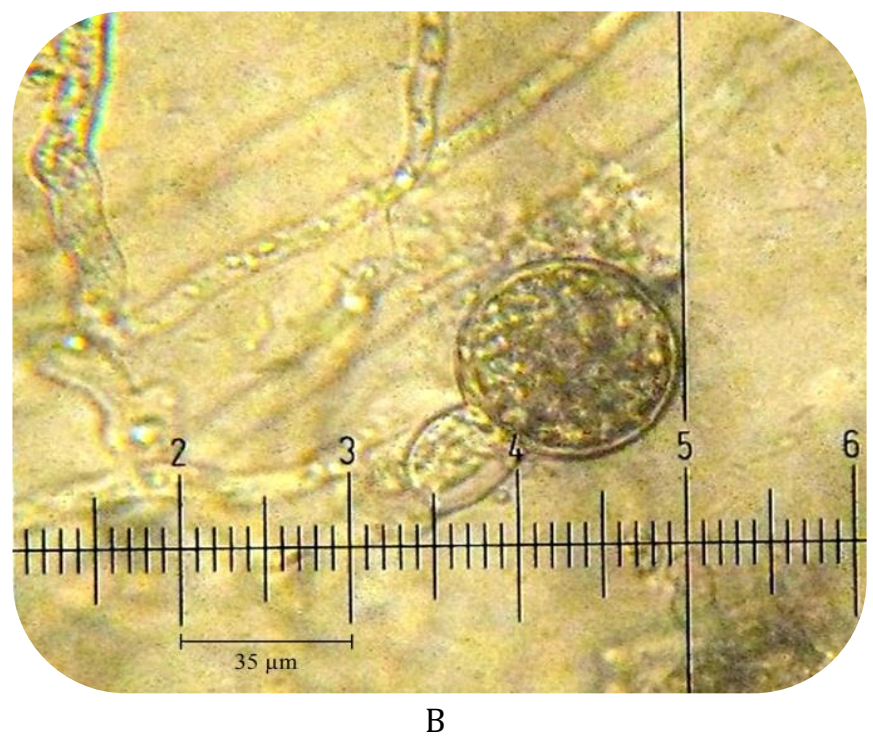

Figure 3. Microscopic view of oospores of Phytophthora infestans, A) hybrid oospore from $\mathrm{A}_{1} \times \mathrm{A}_{2}$ paired cultures, B) self-fertile oospore from $\mathrm{A}_{1} \times \mathrm{A}_{1}$ paired cultures.

\section{DISCUSSION}

It is a very important problem whether $A_{2}$ mating type occur in the main potato production regions, because the occurrence of $\mathrm{A}_{2}$ mating type means oospores formation and sexual reproduction of the pathogen in the life cycle. Sexual reproduction may generate genetic recombination and produce more virulent physiological races and may increase primary infection sources of the diseased, because oospores can overwinter in the remainders and soil (Zhang et al., 2001). The monitoring of $A_{1}$ and $A_{2}$ mating type ratios is important to aid in the prediction of the extent of sexual recombination and thus the risk of long-lived oospores serving as primary inoculum sources. A study of the distribution of the $A_{1}$ and $A_{2}$ strains of Ph. infestans is fundamental to understanding the significance of mating type to both the generation and maintenance of genetic diversity and to disease aetiology (Cooke and Lees, 2004).

Afzali et al. (2008); for the first time observed the occurrence of the $A_{2}$ mating types from the potato producing farms of Ardabil province of Iran. Zolfaghary and Gran (2015), have reported the first occurrence and distribution of the $A_{2}$ mating type of Ph. infestans from the potato fields in Golestan province in the north-east of Iran. These results after the first report on occurrence of the $\mathrm{A}_{2}$ mating type in Golestan province confirm the second detection of the $\mathrm{A}_{2}$ mating type of Ph. infestans in Golestan province of Iran and show the distribution of both mating types in several major potato producing regions. The results of this study indicated that the ratio of the $A_{1}$ to $A_{2}$ mating types of Ph. infestans from two regions: Valikabad and Feyzabad was almost 6:1 for the benefit of the $A_{1}$ mating type for every three years. Afzali et al. (2008), have reported that the ratio of the $A_{1}$ to $A_{2}$ mating types of Ph. infestans from Ardabil province was 83.87 to $16.13 \%$, almost $5: 1$ for the benefit of $A_{1}$ mating type. Zolfaghary and Gran (2015); have reported that this ratio was 86.18 to $13.82 \%$, almost $6: 1$ for the benefit of the $A_{1}$ mating type in Golestan province. This ratio is not suitable for sexual reproduction in natural populations of $P h$. infestans in potato fields. Therefore, the average value for oospore production index (OPI) for the $A_{1}$ to $A_{2}$ mating types of $P h$. infestans from Valikabad and Feyzabad in potato blighted tissues (in vivo) can be 
less than OPI in paired cultures (in vitro). The presence of the $\mathrm{A}_{2}$ mating type during three years of research in Valikabad and Feyzabad perhaps was related to the conditions of Metalaxyl using in these regions. This systemic fungicide had been used more generally and earlier for several years in these regions. Metalaxyl was rarely used in Jelin, Sorkhankalateh and Marzankalateh. Thus, long time application of metalaxyl perhaps induced $A_{1}$ mating type turning into $A_{2}$ (Ann and Ko, 1988; Chang and Ko, 1990; Zhang et al., 2001; Savenkova and Cherepennikova, 2002).

The presence of the $A_{1}$ self-fertile isolates only in Valikabad and Feyzabad perhaps was related to the effect of metalaxyl on the $A_{1}$ isolates (Elliot, 1983). On the other hand, potato cultivars which cultivated in Valikabad and Feyzabad (Agria and Marfona) for several years were susceptible to foliar late blight. Ranjbar et al. (2012), have reported that two potato cultivars namely, Agria and Marfona were susceptible to late blight on foliage. Zargarzadeh et al. (2008); were found that there were significant correlations between climatic factors, particularly temperature and rainfall, with the incidence of the late blight. It can be concluded that under the condition of about $30 \mathrm{~mm}$ rainfall and higher temperatures of about $19^{\circ} \mathrm{C}$ during the critical period of the growing season, we must expect the development of the potato late blight disease and must use preventive measure immediately. The weather data, including temperature, relative humidity and rainfall were obtained from the synoptic weather station of Golestan province in 2014-15, indicated that the weather conditions were favorable for the growth of pathogen of potato late blight. But, in 2016, reduction of rainfall and drought in Golestan province reduced the total number of isolates from 70 to 57. Our findings indicated that the self-fertile isolates only belonged to the $A_{1}$ mating type of Ph. infestans. Afzali et al. (2008); from Ardabil province have reported that self-fertile isolates of $P h$. infestans only belonged to the $A_{1}$ mating type. Our investigation indicated that oospores of 197 isolates of Ph. infestans, obtained from the most of the potato growing regions from different fields in Golestan province of Iran (in vitro) had hybrid and self-fertile origins. Smirnov (2001); has categorized oospores of Ph. infestans into three kinds (hybrid, self-fertile and parthenogenetic) from point of the view of origin. The hybrid oospores are formed as cross-fertilization with a participation of $P h$. infestans mycelia of different mating types. Self-fertile oospores are formed as self-fertilization with participation of only one $P h$. infestans mycelium. Parthenogenetic oospores can be formed as parthenogenesis- from unfertilized oogonia. Smirnov (2001); has suggested that the modern laboratory techniques (tracing of the hyphae, GUS gene transformation and genetic analysis of matings) are shown to be ineffective for determination of these types of oospores of Ph. infestans (hybrid, self-fertile and parthenogenetic) in the field populations. He suggested to analyze the oospore micromorphology (size, thickness of the wall, the form of oogonium and presence of antheridium) and mating types of the strains producing the investigated oospores. The analysis of these features should allow to distinguish all three kinds of $P h$. infestans oospores in vitro. Smirnov (2001); has reported that in vitro, oospores of Ph. infestans had 15-60 $\mu \mathrm{m}$ in diameter. The hybrid oospores had sherical form, with antheridia, with two or more thick walls and often 25-35 $\mu \mathrm{m}$ in diameter. The self-fertile oospores had sherical form with a thin wall and often 40-60 $\mu \mathrm{m}$ in diameter. The parthenogenetic oospores had half spherical form with spheroid oogonia with a thin wall and often 15-20 $\mu \mathrm{m}$ in diameter. We did not find the parthenogenetic oospores $P$. infestans in isolates obtained from collected samples, but this will require further research.

\section{ACKNOWLEDGMENTS}

The author really and greatly would like to appreciate to Prof. Smirnov Alexei Nikolaevich, Department of Plant Protection, Russian State Agrarian University- Moscow Timiryazev Agricultural Academy for supplying standard tester strains of Ph. infestans for mating type determination and all potato producers in Golestan province of Iran for providing us infected plant materials.

\section{REFERENCES}

Afzali, H. B. S., S. Raeiat-Panah, A. Viani, and D. Ershad. 2008. Occurrence of the A2 mating type and selffertile isolates of Phytophthora infestans, a casual agent of potato late blight. 18th Iranian Plant Protection Congress: pp 39.

Aghajani, M. 2015. A forecasting model for potato late blight in Gorgan. Journal of Agricultural Sciences and Natural Resources, 21: 99-116.

Ann, P. J. and W. H. Ko. 1988. Hormonal Heterothallism in Phytophthora parasitica: A Novel Mode of Sexual Reproduction? Microbiology, 134: 29852992. 
Caten, C. E. and J. L. Jinks. 1968. Spontaneous variability of single isolates of Phytophthora infestans I. Cultural variation. Canadian Journal of Botany, 46 : 329-348.

Chang, T.-t. and W.-h. Ko. 1990. Effect of metalaxyl on mating type of Phytophthora infestans and $P$. parasitica. Japanese Journal of Phytopathology, 56: 194-198.

Cohen, Y., S. Farkash, Z. Reshit and A. Baider. 1997. Oospore Production of Phytophthora infestansin Potato and Tomato Leaves. Phytopathology, 87: 191-196.

Cooke, D. E. L. and A. K. Lees. 2004. Markers, old and new, for examining Phytophthora infestans diversity. Plant Pathology, 53: 692-704.

Drenth, A., E. M. Janssen and F. Govers. 1995. Formation and survival of oospores of Phytophthora infestans under natural conditions. Plant Pathology, 44: 8694.

Elliott, C. G. 1983. Physiology of sexual reproduction in Phytophthora. Phytophthora: Its Biology, Taxonomy, Ecology, and Pathology: 71-80.

Ershad, D. 2009. Fungi of Iran. Iranian Research Institute of Plant Protection: pp 531.

Flier, W. G., N. J. GrÜNwald, W. E. Fry and L. J. Turkensteen. 2001. Formation, production and viability of oospores of Phytophthora infestans from potato and Solanum demissum in the Toluca Valley, central Mexico. Mycological Research, 105: 998-1006.

Forbes, G. 1997. Manual for laboratory work on Phytophthora infestans. CIP's Training Manual.

Fry, W. E. 1993. Historical and Recent Migrations of Phytophthora infestans: Chronology, Pathways, and Implications. Plant Disease, 77: 653.

Gallegly, M. 1958. Mating types and oospores of Phytophthora infestans in nature in Mexico. Phytopathology, 48: 274-277.

Hohl, H. R. and K. Iselin. 1984. Strains of Phytophthora infestans from Switzerland with A2 mating type behaviour. Transactions of the British Mycological Society, 83: 529-530.

Lehtinen, A., B. Andersson, V. H. Le, R. Naerstad, M. Rastas, E. Ketoja, A. O. Hannukkala, A. Hermansen, B. J. Nielsen, J. G. Hansen and J. Yuen. 2009. Aggressiveness of Phytophthora infestans on detached potato leaflets in four Nordic countries. Plant Pathology, 58: 690-702.
Mazáková, J., V. Táborský, M. Zouhar, P. Ryšánek, E. Hausvater and P. Doležal. 2010. Occurrence and distribution of mating types A1 and A2 of Phytophthora infestans (Mont.) de Bary in the Czech Republic. Plant Protection Science, 42: 4148.

Rafiee, V. a. Z. B. 2015. Tomato agar can be a suitable substitute for CV-8 agar for sporulation of various species of Phytophthora. 2nd Iranian Mycological Congress: p. 69.

Ranjbar, M., E. M. NASR and S. Salehi. 2012. Phenology and morphological diversity of the main potato cultivars in Iran.

Sadravi, M. 2008. Important field crops diseases of Iran Department of Plant Protection, Natural Resources: p. 193.

Savenkova, L. V. and M. I. Cherepennikova-Anikina. 2002. Effect of metalaxyl and N-nitro-Nnitrosomethylurea on mating type of Phytophthora infestans. J. Russ. Phytopathol, 3: 33-38.

Shaw, D. 1996. Genetic Analysis in the Oomycetous Fungus. Fungal genetics: principles and practice, 13: 407.

Smirnov, A. and S. Elansky. 1999. Oospore formation in the field populations of Phytophthora infestans in Moscow region. Mikologiya-I-Fitopatologiya, 33: 421-425.

Smirnov, A. N. 2001. Identification of source of oospores in field populations of Phytophthora infestans. Izvestiya of Timiryazev Agricultural Academy,Moscow, Russian Federation., 1: 141153.

Smoot, J. J. F. J. G., H. A. Lamey, J. J. Eichenmuller, and M. E. Gallegly. 1958. Production and germination of oospores of Phytophthora infestans. Phytopathology, 48: 165-171.

Spielman, L. J., A. Drenth, L. C. Davidse, L. J. Sujkowski, W. Gu, P. W. Tooley and W. E. Fry. 1991. A second world-wide migration and population displacement of Phytophthora infestans? Plant Pathology, 40: 422-430.

Tooley, P. W. 1989. Mating Type, Race Composition, Nuclear DNA Content, and Isozyme Analysis of Peruvian Isolates of Phytophthora infestans. Phytopathology, 79: 478.

Zargarzadeh, F., A. Ghorbani, A. Asghari and G. NouriGanbalani. 2008. The effect of climatic factors on 
potato late blight disease in Ardabil plain of Iran. Journal of Food, Agriculture \& Environment, 6: 200-205.

Zhang, Z., J. Zhu, B. Song, Y. Li, S. Tian and H. Jiang. 2001. Further investigations on A2 mating type of Phytophthora infestans in China. Journal of Hebei
Agricultural University, 24: 32-37.

Zolfaghary, A. a. A. G. 2015. Occurrence, distribution and frequency of $\mathrm{A} 1$ and $\mathrm{A} 2$ mating types in Oomycetes Populations Phytophthora infestans (Mont.) de Bary, pathogen of potato late blight. 2nd Iranian Mycological Congress: p. 99. 